\title{
DESAIN ARSITEKTUR IOT UNTUK BUDIDAYA GURAMI
}

\author{
Yupit Sudianto*1 \\ ${ }^{1 *}$ Program Studi Sistem Informasi, Institut Teknologi Telkom Surabaya \\ Email: ${ }^{1}$ yupit@ittelkom-sby.ac.id \\ *Penulis Korespondensi
}

(Naskah masuk: 04 Mei 2020, diterima untuk diterbitkan: 01 Februari 2021)

\begin{abstract}
Abstrak
Sektor perikanan di Indonesia memiliki potensi bagus untuk dikembangkan. Dengan pengelolaan yang baik, sektor ini dapat memberikan kontribusi bagi ketahanan pangan nasional dan meningkatkan kesejahteraan bagi masyarakat Indonesia. Salah satu sektor perikanan yang menarik untuk dibudidayakan adalah ikan gurami. Gurami banyak diminati oleh masyarakat dan memiliki harga jual yang stabil. Namun, kendala dalam budidaya gurami adalah pertumbuhan yang lambat, biaya pakan yang tinggi, dan tingkat kelangsungan hidup yang rendah. Seiring dengan perkembangan teknologi internet of things (IoT) dewasa ini, tentunya teknologi ini dapat memberikan solusi bagi pembudidaya gurami untuk mengatasi kendala tersebut. Oleh karena itu, pada penelitian ini diusulkan arsitektur IoT untuk budidaya gurami. Arsitektur IoT yang diusulkan dalam penelitian ini memiliki enam desain yang terdiri dari domain model, business process hierarchy, IoT layer, deployment diagram, information model, dan interoperability endpoint. Dengan adanya arsitektur IoT ini diharapkan sistem IoT yang dibangun sesuai dengan kebutuhan pembudidaya gurami serta memudahkan pengembang untuk membangun dan mengembangkan sistem tersebut.
\end{abstract}

Kata kunci: budidaya ikan gurami, arsitektur ,internet of things (IoT)

\section{IOT ARCHITECTURE FOR GOURAMY CULTIVATION}

\begin{abstract}
The fisheries sector in Indonesia has great potential to be developed. With good management, this sector can contribute to national food security and improve welfare for the people of Indonesia. One of the interesting fisheries sector to be cultivated is gurami. Gurami is much in demand by the public and has a stable selling price. However, growth in gouramy cultivation is slow growth, high food costs, and low survival rates. The development of internet of things (IoT) technology today, this technology can provide solutions for gouramy farmers to overcome these obstacles. Therefore, this research proposes IoT architecture for gouramy cultivation. The IoT architecture proposed in this study has six designs consisting of the domain model, business process hierarchy, IoT layer, deployment, information, and interoperability endpoints. The IoT architecture is expected to build the IoT system in accordance with the needs of gouramy farmers and make it easier for developers to build and develop the system.
\end{abstract}

Keywords: gouramy cultivation, architecture, internet of things (IoT)

\section{PENDAHULUAN}

Sektor perikanan di Indonesia memiliki potensi yang cukup besar. Berdasarkan laporan kinerja pembangunan kelautan dan perikanan bulan Agustus 2019 oleh Kementerian Kelautan dan Perikanan (KKP) terdapat kinerja positif pada berbagai data seperti Produk Domestik Bruto (PDB) perikanan, produksi perikanan, angka konsumi ikan nasional, volume ekspor perikanan, dan nilai ekspor perikanan (Perikanan, 2019). Kontribusi PDB perikanan terhadap PDB Nasional menunjukkan adanya peningkatan, dari rata-rata $2.32 \%$ pada tahun 2014 meningkat menjadi 2.60\% pada tahun 2018 (Gambar 1). Produksi perikanan juga menunjukkan tren yang meningkat pada tahun 2014 sebesar 20.474.506,48 ton meningkat pada tahun 2018 menjadi 24.319.835,37 ton (Gambar 2a). Angka konsumsi ikan nasional sebesar $41.11 \mathrm{~kg} / \mathrm{kapita}$ pada tahun 2015 meningkat menjadi $50.69 \mathrm{~kg} / \mathrm{kapita}$ pada tahun 2018 (Gambar 2b). Pada periode tahun 2017-2018 volume ekspor hasil perikanan menunjukkan peningkatan 4.45\% (Gambar 2c), dan nilai ekspor meningkat $7.44 \%$ (Gambar 2d). Tren peningkatan pada berbagai data tersebut menunjukkan bahwa sektor perikanan memiliki prospek yang cerah, dan 
jika sektor ini dikelola dengan baik diharapkan dapat memberikan kontribusi bagi ketahanan pangan nasional serta meningkatkan kesejahteraan bagi rakyat Indonesia.

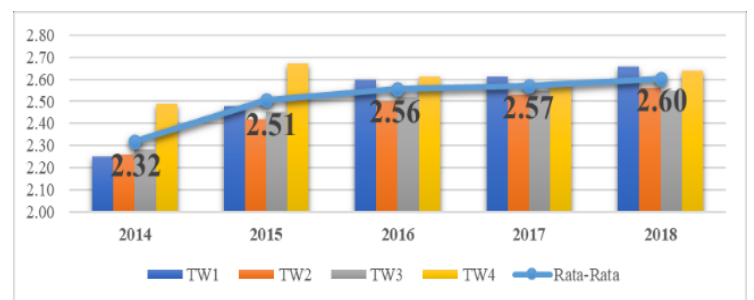

Gambar 1. Grafik Produk Domestik Bruto Perikanan (dalam \%).

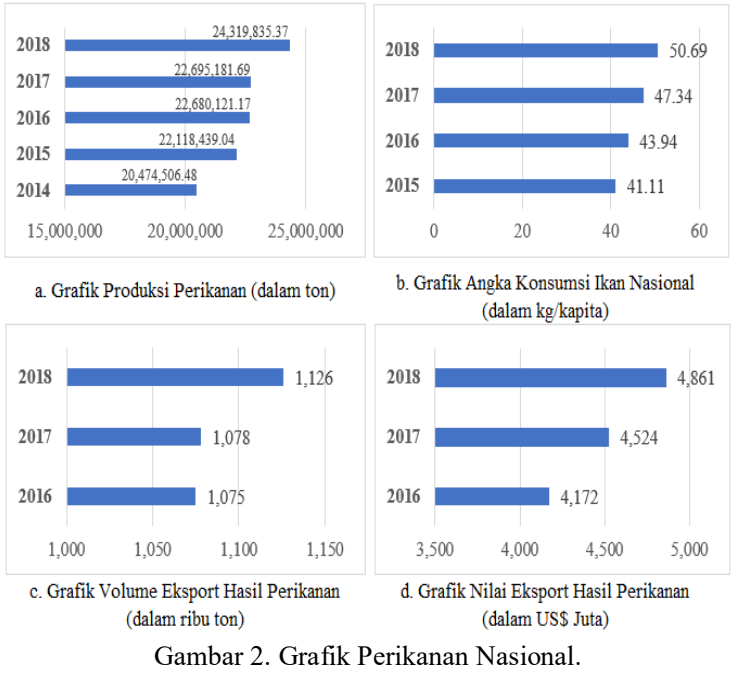

Salah satu sektor perikanan yang menarik untuk dibudidayakan adalah ikan gurami. Gurami banyak diminati masyarakat karena memiliki rasa yang enak dan tekstur daging yang tidak lembek. Harga jual gurami relatif stabil dan mahal (Hardiningsih, 2018).

Tantangan dalam budidaya gurami telah diungkapkan dalam berbagai penelitian. Pertumbuhan gurami yang lambat dan biaya pakan yang cukup besar menjadi permasalahan utama yang dihadapi oleh pembudidaya gurami (Noor dan Pakaya, 2018). Lama budidaya gurami dapat dilihat Tabel 1, pada tabel tersebut diketahui bahwa budidaya gurami terdiri dari 5 segmen dengan lama waktu budidaya adalah 12 bulan. Kendala yang lain adalah serangan bakteri, parasit, dan jamur yang terjadi di Sentra Budidaya Ikan Gurami, Desa Beji, Kecamatan Kedung Banteng, Kabupaten Banyumas, Jawa Tengah (Khumaidi dan Hidayat, 2018). Tingkat kelangsungan hidup gurami yang rendah serta rasio konversi pakan yang tinggi merupakan faktor rendahnya produksi ikan gurami (Wijayanti, Muarif dan Lesmana, 2019). Terbatasnya ketersediaan benih yang disebabkan oleh tingginya tingkat kematian menjadi hambatan dalam budidaya gurami (Jumaidi, Yulianto, dan Efendi, 2017).

Pertumbuhan gurami yang lambat dan rasio konversi pakan yang tinggi dapat ditangani dengan mencampur pakan gurami dengan probiotik EM-4.
Tingkat kematian yang tinggi, kualitas air yang buruk, serta serangan bakteri, parasit, dan jamur yang terjadi pada budidaya gurami dapat ditangani dengan menjaga parameter kualitas air seperti suhu, derajat keasaman $(\mathrm{pH})$, dan oksigen terlarut dalam kondisi optimal. Kondisi optimal dari parameter kualitas air tersebut dapat dilihat pada Tabel 2Tabel 2 (Noor and Pakaya, 2018).

Teknologi internet of things (IoT) yang berkembang dewasa ini, telah diterapkan pada berbagai domain, termasuk pada budidaya perikanan. Teknologi ini telah diimplementasikan pada budidaya lele dengan tujuan untuk membantu pembudidaya lele memantau dan mengendalikan secara otomasi kualitas air kolam lele (Rohadi dkk., 2018). Penerapan IoT yang lain adalah perancangan dan implementasi Alat Pencegahan Dini Kematian Ikan dan Udang (APD KIT) untuk menekan angka kematian ikan dan udang. APD KIT menggunakan sensor suhu air (DS8B20) yang digunakan untuk mengkondisikan suhu air, dan Sensor $\mathrm{PH}$ (SEN06161) yang digunakan untuk mengkondisikan kadar keasaman pada air (Tarnadi dkk, 2015). Namun penelitian-penelitian tersebut masih terbatas pada pemantauan dan pengendalian kualitas air.

Konsep Teknologi internet of things (IoT) adalah sistem yang mengkoneksikan berbagai perangkat seperti sensor, aktuator, prosesor, maupun perangkat lainnya melalui media internet. Penerapan IoT pada budidaya gurami tentunya akan menggunakan berbagai perangkat seperti sensor, aktuator, prosesor, cloud platform, dan perangkat lainnya, serta protokol untuk mengatur komunikasi antar perangkat. Oleh karena itu, agar sistem yang dibangun sesuai dengan kebutuhan dari pembudidaya gurami, serta kemudahan integrasi antar perangkat maka tujuan dari penelitian ini adalah merancang arsitektur IoT untuk budidaya gurami.

Tabel 1. Segmentasi budidaya gurami

\begin{tabular}{cccc}
\hline No. & $\begin{array}{c}\text { Segmen Budi } \\
\text { Daya }\end{array}$ & Pertumbuhan & $\begin{array}{c}\text { Umur } \\
\text { Ikan }\end{array}$ \\
\hline 1 & Pendederan I & $\begin{array}{c}\text { Dari larva hingga } \\
\text { ukuran 1-2 cm } \\
\text { (ukuran kuku). }\end{array}$ & $11-40$ hari \\
\hline 2 & Pendederan II & $\begin{array}{c}\text { Ukuran 1-2 cm } \\
\text { hingga 7-8 cm } \\
\text { (ukuran silet) }\end{array}$ & 3 bulan \\
\hline 3 & Pendederan III & $\begin{array}{c}\text { Ukuran silet hingga } \\
50 \text { gram (ukuran 3- } \\
\text { 4 jari) }\end{array}$ & $\begin{array}{c}4-4.5 \\
\text { bulan }\end{array}$ \\
\hline 4 & Pendederan IV & $\begin{array}{c}\text { Ukuran 50 gram } \\
\text { hingga 250 gram }\end{array}$ & $7-8$ bulan \\
\hline 5 & Pembesaran & $\begin{array}{c}\text { 250 gram hingga } \\
700-800 \text { gram }\end{array}$ & 12 bulan \\
\hline
\end{tabular}

Tabel 2. Parameter Kualitas Air

\begin{tabular}{cc}
\hline Paramter Kaulitas Air & Nilai Optimal \\
\hline Suhu $\left({ }^{\circ} \mathrm{C}\right)$ & $25-30{ }^{\circ} \mathrm{C}$ \\
$\mathrm{pH}$ & $6-8$ \\
Oksigen Terlarut & $3-6 \mathrm{ppm}$ \\
\hline
\end{tabular}

Arsitektur IoT yang diusulkan pada penelitian ini diharapkan dapat mengakomodasi kebutuhan 
pembudidaya gurami untuk memantau dan mengendalikan kondisi kolam gurami, memantau tingkat kelangsungan hidup gurami, dan memantau rasio konversi pakan. Harapan lain dengan adanya arsitektur IoT ini adalah memudahkan pengembang (developers) untuk membangun sistem otomatisnya berbasis IoT, kemudahan untuk mengintegrasikan antar perangkat, dan kemudahan pengembangan sistem selanjutnya.

\section{METODE PENELITIAN}

Metode yang digunakan untuk memodelkan arsitektur IoT pada penelitian ini adalah dengan menggunakan kerangka kerja (framework) arsitektur IoT yang dibuat oleh Verdouw dkk, 2019. Kerangka kerja tersebut dikembangkan secara khusus untuk memodelkan arsitektur sistem otomatis berbasis IoT pada ranah agrikultur dan makanan (Verdouw dkk, 2019).

Perancangan arsitektur IoT dilakukan dengan mendefinisikan enam desain yang meliputi domain model, Business Process Hierarchy, layer IoT, deployment diagram, information model, dan interoperability endpoint. Tahapan untuk memodelkan enam desain tersebut dapat dilihat pada Gambar 3. Proses perancangan diawali dengan mengidentifikasi tujuan organisasi dan kebutuhan dari pemangku kepentingan, yang kemudian dilanjutkan dengan pembuatan domain model dan business process hierarchy. Domain model menggambarkan tujuan dan masalah dalam bentuk domain aplikasi, sedangkan business process hierarchy menggambarkan bisnis dan organisasi. Langkah berikutnya adalah pembuatan information model. Bagian ini fokus pada aspek data. Elemen pada information model harus konsisten dengan kedua desain sebelumnya. Kemudian, dilakukan dengan perancangan IoT layer. IoT layer menggambarkan elemen IoT yang akan gunakan. Desain IoT layer harus konsisten dengan tiga desain sebelumnya. Desain berikutnya yang harus dirancang secara paralel adalah development diagram dan interoperability endpoint. Development diagram menggambarkan element perangkat lunak dengan perangkat keras, sedangkan interoperability endpoint menggambarkan interaksi antar perangkat.

\subsection{Domain Model}

Domain model merupakan pemahaman dan terminologi secara umum untuk desain yang lain. Bagian ini menggambarkan interaksi antara entitas serta luaran yang dihasilkan dari interaksi tersebut. Entitas yang dimaksud adalah aktor, objek utama, dan entitas fisik (binatang, bahan baku, barang, peralatan), dan komponen IoT. Domain model dibuat dengan menggunakan UML class diagram (OMG, 2011).

\subsection{Business Process Hierarchy}

Business process hierarchy menggambarkan proses bisnis dan interaksi didalamnya, termasuk aliran produk dari input material hingga produk akhir. View ini terdiri dari empat layer yaitu physical object layer, production control layer, operations execution layer, dan management information layer. Desain business process hierarchy mengacu pada model referensi dari ISA95, yang merupakan kerangka kerja yang mengintegrasikan otomatisasi perkantoran dengan otomatisasi dan mekanisasi produksi (Unver, 2013).

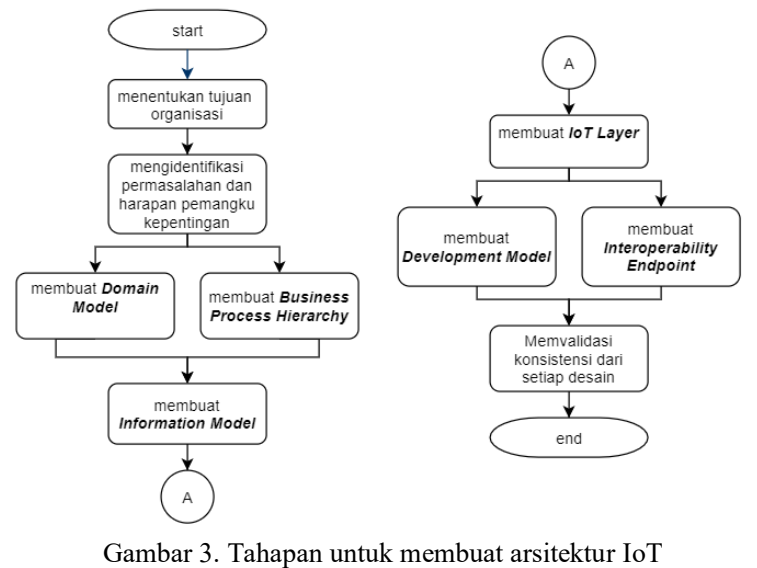

\subsection{IoT Layer}

IoT layer menggambarkan arsitektur teknis serta identifikasi dari infrastruktur atau teknologi yang digunakan. Bagian ini mengklasifikasikan berbagai komponen dengan berdasarkan pada pembagian pada lapisan teknis. Lapisan teknis dibagi menjadi enam bagian yaitu lapisan aplikasi, lapisan layanan pendukung dan aplikasi pendukung, lapisan jaringan, lapisan perangkat, kapabilitas manajemen, dan kapabilitas keamanan, Desain IoT layer mengacu pada model referensi dari ITU-T Y.2060 IoT (Gunturi, Kotha and Srinivasa Reddy, 2018).

\subsection{Deployment Diagram}

Deployment diagram menjelaskan mengenai pengembangan sistem, lokasi perangkat keras dan perangkat lunak, serta bagaimana mengintegrasikan tiga hal tersebut dalam sebuah use case. Deployment diagram digambarkan dalam bentuk UML (OMG, 2011).

\subsection{Information Model}

Information model merupakan model entitas data dari sistem IoT, termasuk data model yang direpresentasikan dalam database, spesifikasi raw data dari sensor, schema standar identification, entitas data pada protokol komunikasi. Information model dibuat dengan menggunakan UML Entity Relationship Diagram (OMG, 2011). 


\subsection{Interoperability Endpoint}

Tujuan dari interoperability endpoint adalah untuk mengidentifikasi antarmuka (interface) yang sesuai antara standar dan protokol yang digunakan dengan sistem IoT yang dikembangkan. Bagian ini merupakan pelengkap dari information model.

\section{HASIL DAN PEMBAHASAN}

Arsitektur IoT dari budidaya gurami yang telah dibuat, akan dibahas pada bagian ini. Pembahasan arsitektur IoT mencakup 6 model, yaitu domain model, business process hierarchy, IoT layer, deployment diagram, information model, dan interoperability endpoint.

Berdasarkan studi literatur yang telah diuraikan pada bagian pendahuluan, permasalahan dalam budidaya gurami adalah pertumbuhan yang lambat, biaya produksi yang tinggi karena banyaknya kebutuhan pakan, tingkat kematian yang tinggi karena kualitas air yang buruk. Oleh karena itu, rancangan sistem IoT untuk budidaya gurami diharapkan dapat mengendalikan kualitas secara otomatis, mengetahui tingkat kematian, mengetahui berapa banyak penggunaan pakan yang telah diberikan, mengetahui perkembangan berat badan dan panjang gurami. Dengan tersedianya data perkembangan berat badan dan panjang gurami, penggunaan pakan, dan tingkat kematian dapat digunakan sebagai pengetahuan bagi pembudidayan mengenai pola budidaya gurami yang dapat memberikan hasil panen yang optimal. Kebutuhan ini diterjemahkan dalam arsitektur IoT yang meliputi 6 model.

\subsection{Domain Model}

Desain domain model dari arsitektur IoT untuk budidaya gurami dapat dilihat pada Gambar 4 . Pembudidaya gurami dapat memantau kondisi kualitas air (suhu air, $\mathrm{pH}$, oksigen terlarut), kondisi gurami (berat, panjang, jumlah kematian), dan rasio konversi pakan melalui dashboard yang dapat diakses dari mana saja, dan melalui berbagai perangkat baik dengan, komputer, laptop, maupun ponsel.

Pekerja adalah orang yang bekerja pada pembudidaya gurami yang kesehariannya berada di lokasi budidaya gurami. Pekerja bertugas menginputkan data berat dan panjang gurami, jumlah pakan yang diberikan, serta jumlah gurami yang mati melalui aplikasi.

Sensor IoT meliputi Sensor $\mathrm{pH}$, suhu air, oksigen terlarut, dan tinggi air berada di setiap kolam gurami dan mengirimkan data ke peyimpanan data secara periodik. Sensor $\mathrm{pH}$ digunakan untuk mengukur kadar keasaman atau basa dari air kolam. Sensor suhu aird digunakan untuk mengetahui suhu daro air kolam. Sensor oksigen terlarut digunakan untuk mengetahui konsentrasi oksigen dari air kolam.

Penyimpanan data digunakan untuk menyimpan data yang berasal dari sensor-sensor yang digunakan, serta input dari user melalui aplikasi. Penyimpanan data menggunakan server lokal dan server internet (cloud server). Data yang tersimpan dalam server lokal secara periodik ke server internet agar dapat diakses oleh pembudidaya dari berbagai lokasi.

Algoritma digunakan untuk mengolah data tersimpan pada server internet. Data tersebut diolah sehingga dapat memprediksi kapan waktu panen serta memberikan informasi kepada pembudidaya mengenai pola budidaya gurami yang paling efektif dan efisien berdasarkan data sebelumnya.

Dashboard merupakan bagian aplikasi yang menampilkan kondisi kualitas air dan gurami saat ini, serta menampilkan data periode sebelumnya yang telah diolah dengan menggunakan algoritma tertentu sehingga dapat memberikan estimasi waktu panen dan mengetahui pola budidaya yang efektif dan efisien berdasarkan data masa lampau. Aplikasi juga digunakan oleh pekerja untuk menginputkan data ke dalam penyimpanan data.

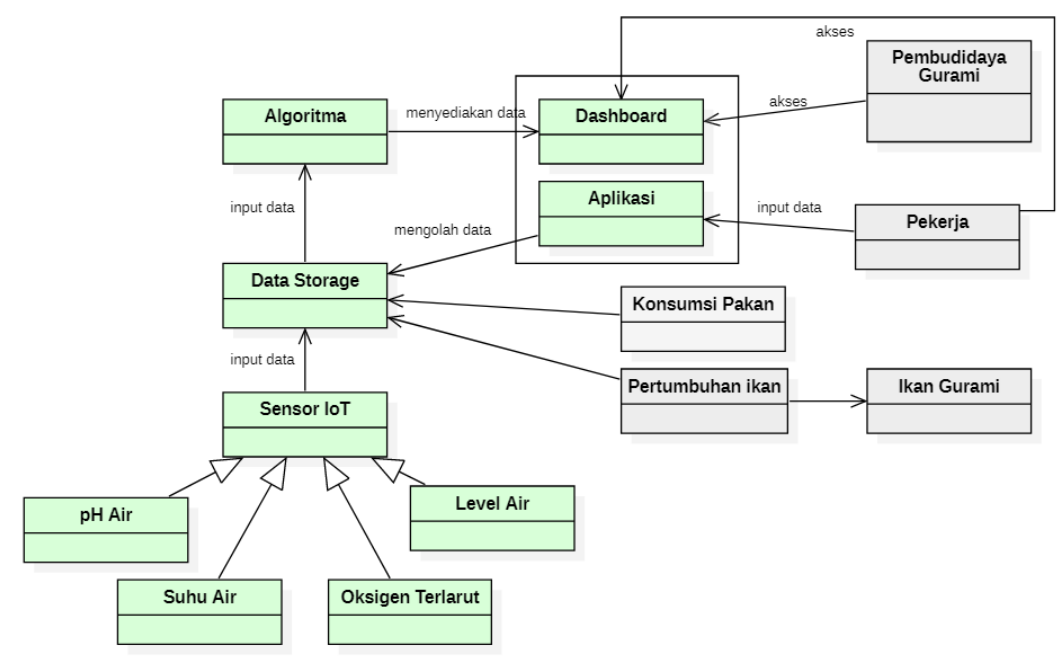

Gambar 4. Rancangan Domain Model untuk Budidaya Gurami 


\subsection{Business Process Hierarchy}

Business process hierarchy memberikan gambaran mengenai proses bisnis dan interaksinya. Agar desain yang disusun sesuai dengan karakteristik IoT maka business process hierarcy didesain berdasarkan ISA95 yang terdiri dari empat lapisan yaitu lapisan objek fisik, lapisan kontrol produksi, lapisan operasi, dan lapisan manajemen informasi (Unver, 2013). Desain business process hierarchy dari arsitektur IoT untuk budidaya gurami dapat dilihat pada Gambar 1Gambar 5.

Lapisan objek fisik merupakan lapisan yang paling bawah. Lapisan ini menggambarkan objek fisik dari proses produksi budidaya gurami yang meliputi pembudidaya gurami, pekerja, pertumbuhan gurami, rasio konversi pakan, dan tingkat kelangsungan hidup. Objek-objek pada lapisan objek fisik berkaitan dengan berikutnya yaitu lapisan kontrol produksi.

Lapisan kontrol produksi merupakan bagian yang menggambarkan pelaksanaan pemantauan dan pengendalian sistem selama proses budidaya gurami. Pada lapisan ini dilakukan pemantauan terhadap konversi pakan, berat dan panjang gurami, dan kualitas air. Kualitas air meliputi tinggi air, $\mathrm{pH}$, Suhu Air, dan Oksigen terlarut. Lapisan kontrol produksi berinteraksi dengan lapisan diatasnya yaitu lapisan operasi.

Lapisan operasi adalah lapisan yang mengelola aliran proses produksi. Lapisan ini menangkap data yang dikirim oleh sensor-sensor yang telah dipasang dan menyimpan data tersebut pada server lokal terlebih dahulu kemudian mengirimkan secara periodik ke server internet. Lapisan ini berinteraksi dengan lapisan manajemen operasi.

Lapisan manajemen informasi merupakan lapisan yang paling atas. Lapisan ini berkaitan dengan perencanaan bisnis dan sistem logistik dari proses produksi di lapisan bawahnya. Pada lapisan ini sistem akan memberikan perkiraan waktu panen dari proses budidaya yang saat ini sedang dilakukan serta memberikan data mengenai pola budidaya yang sudah pernah dilakukan. Dengan mengetahui data dari pola budidaya sebelumnya, pembudidaya gurami akan terbantu dalam menentukan pola budidaya yang paling tepat yang meliputi aspek perencanaan, penjadwalan, dan pelaksanan.

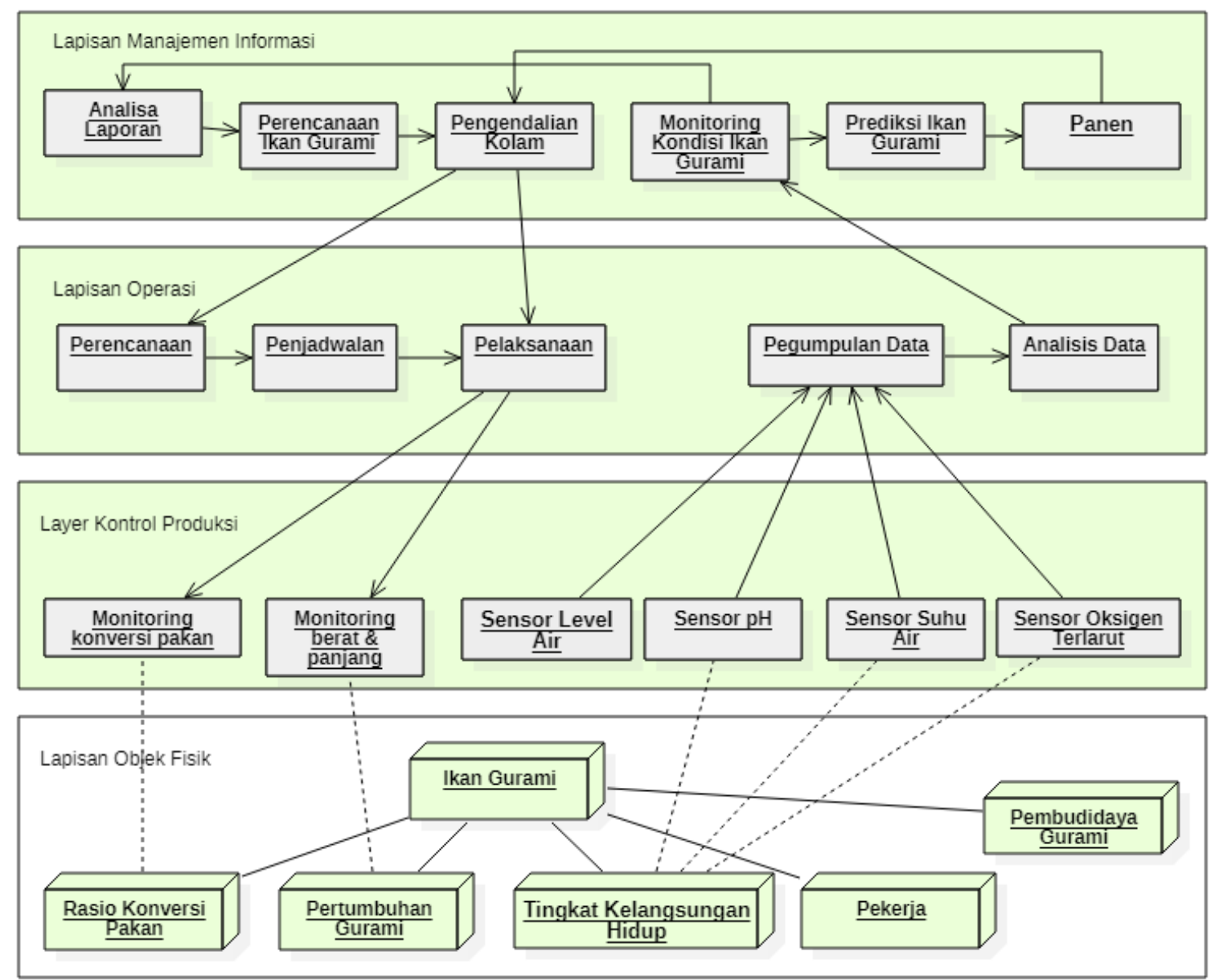

Gambar 5. Rancangan Business Process Hierarchy untuk Budidaya Gurami 


\subsection{IoT Layer}

Desain IoT layer dari arsitektur IoT untuk budidaya gurami dapat dilihat pada Gambar 6. Bagian IoT layer mencakup lapisan aplikasi, lapisan layanan dan aplikasi pendukung, lapisan jaringan, lapisan perangkat, kapabilitas manajemen, dan kapabilitas keamanan.

Pada lapisan aplikasi terdapat IoT dashboard yang berisikan visualisasi data ringkas dari budidaya gurami. Pada lapisan layanan dan aplikasi pendukung mencakup penyimpanan awan (cloud data storage) dan aplikasi web \& perangkat bergerak. Penyimpanan awan digunakan untuk menyimpan data budidaya gurami. Aplikasi web \& perangkat bergerak yang digunakan oleh pekerja untuk menginputkan data berat \& panjang gurami dari setiap kolam dan jumlah kematian dari gurami. Lapisan jaringan berisikan teknologi yang digunakan untuk menyediakan jaringan baik yang berkaitan dengan integrasi antar perangkat maupun mengirimkan data ke penyimpanan awan. Pada bagian ini teknologi yang diusulkan adalah dengan menggunakan Wifi, GPRS, JSON, MQTT. Bagian lapisan jaringan berkaitan dengan kapabilitas manajemen untuk mengatur protokol yang digunakan baik untuk infrastruktur maupun sistem yang digunakan. Kapabilitas keamanan berkaitan dengan keamanan terhadap data, perangkat dan teknologi yang digunakan. Lapisan perangkat mencakup sensor-sensor yang digunakan serta integrasi antar perangkat, baik dengan kabel (wired) maupun tanpa kabel (wireless).

\subsection{Deployment Diagram}

Desain deployment diagram dari arsitektur IoT untuk budidaya gurami dapat dilihat pada Gambar 7 . Komponen yang dikembangkan dalam rancangan ini dibagi menjadi dua bagian yaitu server lokal dan server internet.

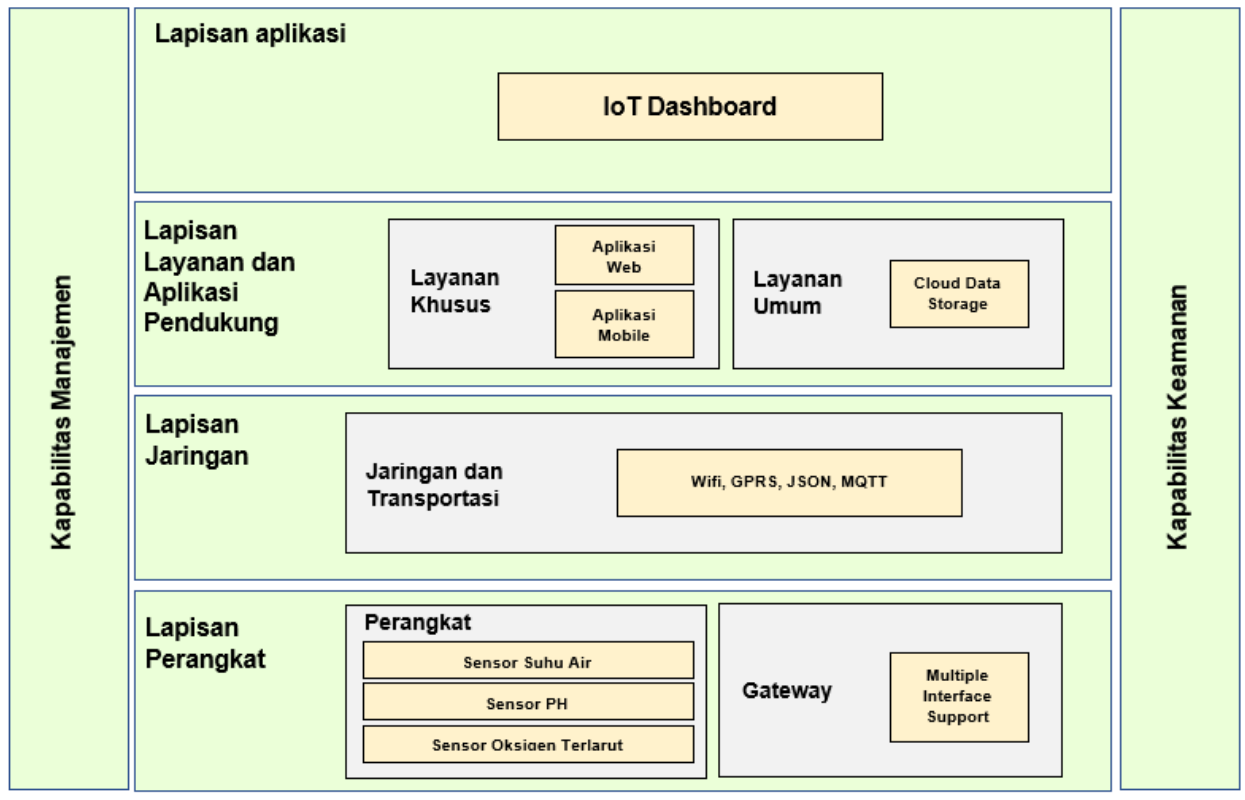

Gambar 6. Rancangan IoT Layer dari Arsitektur IoT untuk Budidaya Gurami

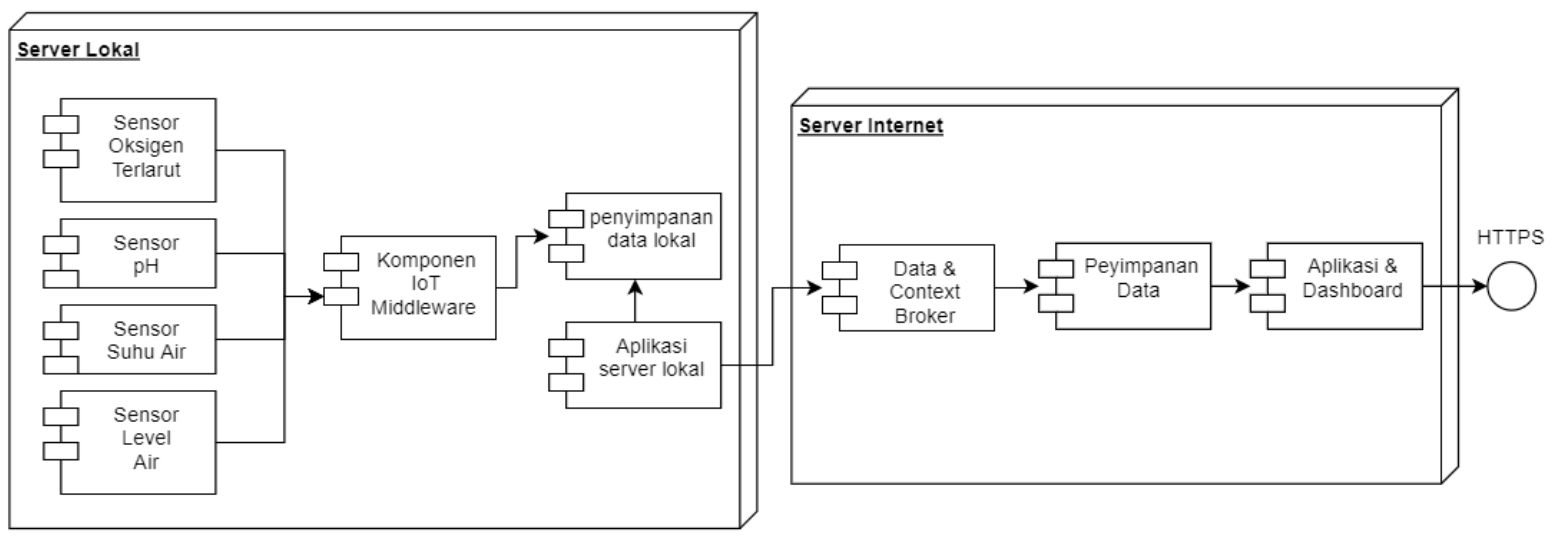

Gambar 7. Rancangan Deployment Model untuk Budidaya Gurami 
Server lokal berada di area budidaya. Komponen dari server lokal adalah sensor oksigen terlarut, sensor $\mathrm{pH}$, sensor suhu air, sensor level air, komponen IoT middleware, penyimpanan data lokal dan aplikasi server lokal. Masing-masing sensor mengirimkan datanya melalui komponen IoT middleware yang kemudian diteruskan kepada penyimpanan data lokal. Kemudian secara periodik aplikasi server akan mengirimkan data kepada server internet.

Server internet merupakan sistem komputasi awan (cloud system) yang mencakup data \& contex broker, penyimpanan data, dan aplikasi \& dashboard. Data \& contex broker berperan dalan menerima data dari server lokal, kemudian menghubungkan dengan penyimpanan data. Data dan informasi yang ditampilkan pada aplikasi dan dashboard didapatkan dengan mengakses penyimpanan data, melalui HyperText Transfer Protocol over Secure Socket Layer (HTTPS).

\subsection{Information Model}

Desain information model dari arsitektur IoT untuk budidaya gurami dapat dilihat pada Gambar 8 .
Pembudidaya gurami dapat memiliki kolam lebih dari satu, sehingga kolam memiliki kode yang unik. Kode unik tersebut akan dilekatkan dengan data dari sensor dan data kesehatan ikan. Data sensor meliputi $\mathrm{pH}$, oksigen terlarut, suhu air, level air. Data kesehatan ikan mencakup panjang dan berat ikan. Setiap data tersebut akan dicatat secara periodik.

Data pakan digunakan untuk menyimpan berapa banyak pakan yang telah di berikan kepada gurami setiap harinya. Data pakan akan berkaitan dengan rasio konversi pakan. Data tingkat kematian digunakan untuk mencatat jumlah ikan yang mati, dengan data ini dapat diketahui tingkat kelangsungan hidup dari gurami.

\subsection{Interoperability Endpoint}

Interoperability endpoint dari budidaya gurami dapat dilihat pada Tabel 3. Bagian ini merupakan gambaran antarmuka untuk mengkoneksikan suatu perangkat dengan perangkat yang lain.

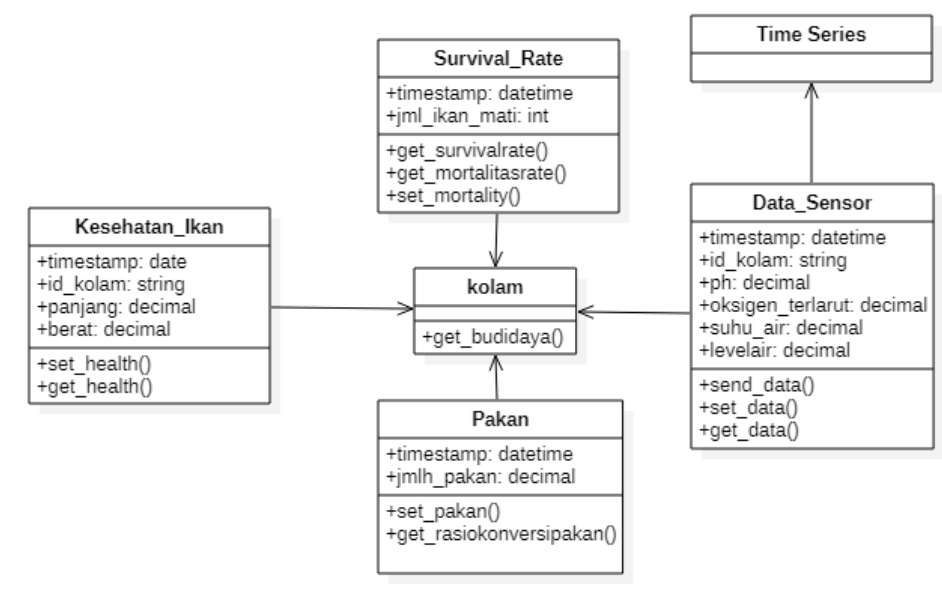

Gambar 8. Rancangan Information Model untuk Budidaya Gurami.

Tabel 3. Interoperability Endpoint untuk Budidaya Gurami

\begin{tabular}{cllll}
\hline No. & Antarmuka & Domain & Protokol & Catatan \\
\hline 1 & $\begin{array}{l}\text { Antarmuka sensor } \\
\text { ketinggian air }\end{array}$ & Sensor ketinggian air & Wire & Sensor di koneksikan dengan menggunakan kabel \\
\hline 2 & Antarmuka sensor ph & Analog PH Sensor & $\begin{array}{l}\text { BNC Connector dan } \\
\text { PH Interface Circuit }\end{array}$ & Sensor di koneksikan dengan menggunakan kabel \\
\hline 3 & Antarmuka sensor suhu air & Sensor Suhu Air & 1-Wire & Sensor di koneksikan dengan menggunakan kabel \\
\hline 4 & $\begin{array}{l}\text { Antarmuka sensor oksigen } \\
\text { terlarut }\end{array}$ & $\begin{array}{l}\text { Sensor Oksigen terlarut } \\
\text { Dissolved Oxygen }\end{array}$ & UART & Sensor di koneksikan dengan menggunakan kabel \\
\hline & Antarmuka sensor suhu & Sensor Suhu & 1-Wire & Sensor di koneksikan dengan menggunakan kabel \\
\hline 5 & Antarmuka server lokal. & Middleware Component & MQTT & $\begin{array}{l}\text { Lapisan aplikasi ditentukan pada saat } \\
\text { pengembangan. }\end{array}$ \\
\hline 6 & Cloud service DB interface & Cloud data storage & HTTP & $\begin{array}{l}\text { Application level ditentukan pada saat } \\
\text { pengembangan. }\end{array}$ \\
\hline 7 & $\begin{array}{l}\text { Interface data \& Context } \\
\text { Broker }\end{array}$ & Cloud Service Platform & NGSI & $\begin{array}{l}\text { Koneksi antara data yang dikirim dari } \\
\text { middleware component ke } \text { cloud. }\end{array}$ \\
\hline
\end{tabular}




\section{KESIMPULAN}

Kerangka kerja Arsitektur IoT yang digunakan pada penelitian ini sangat mempermudah proses penyusunan arsitektur IoT untuk budidaya gurami. Keuntungan yang didapat dengan menerapkan kerangka kerja ini adalah arsitektur IoT yang disusun sesuai dengan kebutuhan dari pembudidaya gurami, kesesuaian tersebut dapat dilihat pada bagian domain model dan business process hierarchy yang dibahas pada sub bab 3.1 dan 3.2. Keuntungan yang lain adalah memudahkan pengembang untuk membangun dan mengembangkan sistem IoT. Kemudahan bagi pengembang dapat dilihat dari sub bab 3.3 hingga 3.6. Sub bab 3.3 memberikan gambaran kepada pengembang mengenai infrastruktur dan teknologi yang digunakan. Sub bab 3.4 menggambarkan lokasi dari setiap komponen yang digunakan. Sub bab 3.5 information model menggambarkan data-data yang akan digunakan. Sub bab 3.6 interoperability endpoint menggambarkan antarmuka yang diperlukan untuk integrasi antar perangkat.

Arsitektur IoT yang diusulkan dalam penelitian ini masih dapat dikembangkan lebih lanjut, beberapa pengembangan yang dapat dilakukan adalah estimasi biaya yang diperlukan untuk membangun sistem IoT, mengimplementasikan arsitektur IoT, arsitektur dapat dilanjutkan dengan pengendalian kondisi kolam secara otomatis, dan lain sebagainya

\section{DAFTAR PUSTAKA}

HARDININGSIH, I., 2018. Budidaya Gurami untuk Ketahanan Pangan dan Eradikasi Kemiskinan di Pedesaan: Peluang dan Tantangan. Seminar Nasional Tahunan XV Hasil Penelitian Perikanan dan Kelautan.

ISA, 2010. ANSI/ISA-95.00.01-2010 (IEC 62264-1 Mod) Enterprise-Control System Integration - Part 1: Models and Terminology.

JUMAIDI, A., YULIANTO, H. dan EFENDI, E., 2017. Pengaruh Debit Air Terhadap Perbaikan Kualitas Air Pada Sistem Resirkulasi dan Hubungannya dengan Sintasan dan Pertumbuhan Benih Ikan Gurame (Oshpronemus gouramy). e-Jurnal Rekayasa dan Teknologi Budidaya Perairan, 5(2), pp.587-596.

KEMENTERIAN KELAUTAN DAN
PERIKANAN, 2019. Kinerja Pembangunan
Kelautan dan Perikanan. (Agustus).

KHUMAIDI, A. dan HIDAYAT, A., 2018. Identifikasi Penyebab Kematian Massal Ikan Gurami (Osphronemus gouramy) Di Sentra Budidaya Ikan Gurami, Desa Beji, Kecamatan Kedung Banteng, Kabupaten Banyumas, Jawa Tengah. Journal of Aquaculture Science, 3(2), pp.145-153.
NOOR, S.Y. dan PAKAYA, R., 2018. Pengaruh Penambahan Probiotik EM-4 (Evective Mikroorganism-4) Dalam Pakan Terhadap Pertumbuhan Dan Kelangsungan Hidup Ikan Gurame (Osprhronemus gouramy). Gorontalo Fisheries Journal, 1(1), p.51.

OMG, 2011. UML 2.4.1 Superstructure Specification. October, 02(August), pp.1732.

ROHADI, E., ADHITAMA, D.W., ASMARA, R.A., ARIYANTO, R., SIRADJUDDIN, I., RONILAYA, F. dan SETIAWAN, A., 2018. Sistem Monitoring Budidaya Ikan Lele Berbasis Internet of Internet of Things Based Water Monitoring System for Catfish. JTIIK, 5(6), pp.745-750.

TARNADI, A., Gemi, G.S., CAHYANTI, E.D. dan Badriyah, Y.E., 2015. Alat Pencegahan Dini Kematian Ikan dan Udang TERHADAP PERUBAHAN SUHU DAN pH. Pelita Jurnal Penelitian Mahasiswa UNY, 0(2), pp.1-12.

UNVER, H.O., 2013. An ISA-95-based manufacturing intelligence system in support of lean initiatives. International Journal of Advanced Manufacturing Technology, 65(5-8), pp.853-866.

VERDOUW, C., SUNDMAEKER, H., TEKINERDOGAN, B., CONZON, D. dan MONTANARO, T., 2019. Architecture framework of IoT-based food and farm systems: A multiple case study. Computers and Electronics in Agriculture, [online] 165(April), p.104939.

WIJAYANTI, R., MUARIF, M. dan LESMANA, D., 2019. Tingkat Kelangsungan HIDUP DAN Rasio Konversi Pakan Pada Budidaya Ikan Gurami (Osphronemus goramy LAC.) dengan Sistem Bioflok dan Pemberian Pakan Kadar Protein yang Berbeda. Jurnal Mina Sains, 5(1), pp.42-49. 